IZA DP No. 9874

Social Capital, Entrepreneurship and Living Standards:

Differences between Immigrants and the Native Born

Matthew Roskruge

Jacques Poot

Laura King

April 2016 


\title{
Social Capital, Entrepreneurship and Living Standards: Differences between Immigrants and the Native Born
}

\author{
Matthew Roskruge \\ NIDEA, University of Waikato \\ Jacques Poot \\ NIDEA, University of Waikato \\ and IZA \\ Laura King \\ NIDEA, University of Waikato
}

Discussion Paper No. 9874

April 2016

IZA
P.O. Box 7240
53072 Bonn
Germany

Phone: +49-228-3894-0

Fax: +49-228-3894-180

E-mail: iza@iza.org

Any opinions expressed here are those of the author(s) and not those of IZA. Research published in this series may include views on policy, but the institute itself takes no institutional policy positions. The IZA research network is committed to the IZA Guiding Principles of Research Integrity.

The Institute for the Study of Labor (IZA) in Bonn is a local and virtual international research center and a place of communication between science, politics and business. IZA is an independent nonprofit organization supported by Deutsche Post Foundation. The center is associated with the University of Bonn and offers a stimulating research environment through its international network, workshops and conferences, data service, project support, research visits and doctoral program. IZA engages in (i) original and internationally competitive research in all fields of labor economics, (ii) development of policy concepts, and (iii) dissemination of research results and concepts to the interested public.

IZA Discussion Papers often represent preliminary work and are circulated to encourage discussion. Citation of such a paper should account for its provisional character. A revised version may be available directly from the author. 


\section{ABSTRACT}

\section{Social Capital, Entrepreneurship and Living Standards: Differences between Immigrants and the Native Born ${ }^{1}$}

Both migrant entrepreneurship and social capital are topics which have attracted a great deal of attention. However, relatively little econometric analysis has been done on their interrelationship. In this paper we first consider the relationship between social capital and the prevalence of entrepreneurship. We also investigate the relationship between social capital and the living standards of entrepreneurs. In both cases we ask whether these interrelationships differ between migrants and comparable native-born people. We utilize unit record data from the pooled 2008, 2010 and 2012 New Zealand General Social Surveys (NZGSS). The combined sample consists of 15,541 individuals who are in the labour force. Entrepreneurs are defined as those in the sample who obtained income from self-employment or from owning a business. Social capital is proxied by responses to questions on social networks, volunteering and sense of community. The economic standard of living is measured by either personal income or by an Economic Living Standards Index (ELSI) score developed by the New Zealand Ministry of Social Development. We find significant differences between migrants and the native born in terms of the attributes of social capital that are correlated with entrepreneurship, but volunteering matters equally for both groups. The positive association between social capital attributes and ELSI scores is similar between migrant and natives. Social capital contributes little to explaining incomes of either group.

JEL Classification: F22, J15, L26, Z13

Keywords: migration, social capital, entrepreneurship, income, standard of living

Corresponding author:

Matthew Roskruge

National Institute of Demographic and Economic Analysis (NIDEA)

University of Waikato

Private Bag 3105

Hamilton 3240

New Zealand

E-mail: mattr@waikato.ac.nz

\footnotetext{
1 This paper is forthcoming as a chapter in the Edward Elgar Handbook on Social Capital and Regional Development, edited by Hans Westlund and Johan P. Larsson. This study has been supported by the 2007-2012 Integration of Immigrants Programme (IIP), funded by Foundation for Research, Science and Technology grant MAUX0605 and the 2014-2020 Capturing the Diversity Dividend of Aotearoa New Zealand (CaDDANZ) programme, funded by Ministry of Business Innovation and Employment grant UOWX1404. We thank Robert Tanton, other participants at the $61^{\text {st }}$ North American Meetings of the Regional Science Association International in Washington DC, November 2014, and three anonymous referees for their helpful comments. Access to the data used in this study was provided by Statistics New Zealand under conditions designed to keep individual information secure in accordance with requirements of the Statistics Act 1975. The views, opinions, findings and conclusions are strictly those of the authors and do not necessarily represent an official view of Statistics New Zealand or of the organisations at which the authors are employed.
} 


\section{Introduction}

The topics of migrant entrepreneurship and social capital have been widely discussed in the academic literature, yet there remains a lack of empirical analysis of the interrelationship between these two topics. Ethnic social capital, i.e. linkages between actors facilitated in part by a common ethnicity, can be an economic resource for ethnic entrepreneurship (Tolciu, 2011; Sequeira and Rasheed, 2006). Hence in this age of ethnically diverse cross-border migration flows we need a better understanding of the potentially different ways in which social capital can enhance entrepreneurial success among migrants and non-migrants (Galbraith et al., 2007).

In this paper, we use data from New Zealand to test for differences between the native born and immigrants in the ways in which social capital is associated with entrepreneurship. Secondly, for those who are entrepreneurs, we assess the extent to which social capital affects the benefits of entrepreneurship and, again, whether there are differences between migrants and the native born. We measure these benefits in terms of an index of living standards and in terms of personal income.

The empirical data for this research consist of the merged 2008, 2010 and 2012 Confidentialised Unit Record Files (CURFs) of the New Zealand General Social Survey (NZGSS). The NZGSS has not been specifically designed for studying entrepreneurship, but has the advantage of providing many characteristics of individuals that may be associated with entrepreneurship.

Our results show a positive partial correlation between some proxies of social capital and the prevalence of entrepreneurship in the community. Those who do volunteer work are significantly more likely to be entrepreneurs, and this applies to both the native born and immigrants. In the absence of suitable instruments, we cannot assess explicitly whether this partial correlation is causal. Nonetheless, the evidence is supportive of the idea that volunteering is an activity positively associated with entrepreneurship. This is in line with the finding of Westlund (2011) that entrepreneurship is multidimensional and that the different types of entrepreneurship may reinforce each other. In the present context, earning income from self-employment or from running a business may be referred to as economic entrepreneurship, while volunteering is a form of social entrepreneurship. However, there is no evidence in our data that volunteering "pays off" to entrepreneurs in a pecuniary sense. The living standards and incomes of entrepreneurs who engage in volunteering are not higher than those of entrepreneurs who do not. Instead, strong networks do appear to pay off in the sense that entrepreneurs who do not feel isolated from others have higher living standards and income.

With respect to comparing immigrants and the native born, we find some significant differences in terms of the attributes of social capital that determine self-employment and business ownership. Generally, an immigrant's propensity to be an entrepreneur increases with years lived in New Zealand. Ethnicity is also an important determinant of entrepreneurship. Ceteris paribus, people who identify as 
Māori or Pacific Islander are less likely to be entrepreneurs. ${ }^{2}$ Additionally, the economic outcomes for immigrant entrepreneurs who identify as of Pacific Island and/or Asian ethnicity are worse than those of New Zealand born entrepreneurs of European ethnicity. The impact of social capital on Economic Living Standards Index (ELSI) scores is very similar between migrant and natives. Social capital contributes little to explaining incomes of either group.

We begin with a short review of the recent literature on linkages between social capital, entrepreneurship and immigration. Next, the data and methodology section provides information about the NZGSS and the econometric techniques utilised. The key results from various regression models examining the prevalence and outcomes of entrepreneurship, and the role of social capital and migrant status in these models, are given in Section 4. The final section reflects on these empirical findings, draws conclusions and suggests areas of future research.

\section{Literature Review}

In recent decades the world has witnessed rapid growth in the volume and complexity of international migration flows. At the beginning of 2016, an estimated 250 million people (3.4 percent in the world population) were living abroad. There is wide consensus in the literature that migrants are more likely to be entrepreneurs than their native-born counterparts (Fairlie and Lofstrom, 2015; OECD, 2010; Pendakur and Mata, 1999) and that social capital influences how successful migrant entrepreneurs are (Sequeira and Rasheed, 2006). Some of the mechanisms by which social capital can contribute to the success of entrepreneurship have been explored by Westlund and Gawell (2012). They discuss how social capital facilitates the mobilization of resources through the information and resources held within a social network, thereby assisting in the operationalization of exploiting business opportunities. Social capital contributes not only to the success of entrepreneurs but can also explain, along with attitudes to risk and entrepreneurial capital, why some people choose to undertake new business ventures while others do not (De Carolis and Saparito, 2006).

Sahin and Ilhan-Nas (2011) split the determinants of ethnic entrepreneurship into two categories: push factors and pull factors. Migrants may be pushed into entrepreneurship due to difficulties in finding suitable jobs, for example due to discrimination in the labour market. This is also referred to as 'necessity entrepreneurship' (e.g., Reynolds et al., 2002; Sternberg et al., 2006; Block and Wagner, 2010). Self-employment may be seen in this case as the only option for socioeconomic improvement (Constant and Zimmerman, 2006). Levie (2007) found that perceived disadvantage in the

\footnotetext{
${ }^{2}$ In the New Zealand population census, respondents can state as many ethnicities as they feel they belong to. About 14 percent of the 2013 census population stated Māori ethnicity and 7.6 percent stated one of the Pacific Island ethnicities.
} 
UK labour market was one of the main reasons for migrants' entry into entrepreneurship there. Migrants are more likely to report feeling discriminated in the local labour market when they have insufficient language skills, unrecognized qualifications and a lack of knowledge about how the host labour market operates. This is supported in the New Zealand context by Daldy et al. (2013) who found that workplace discrimination is significantly higher among foreign-born workers than New Zealandborn workers. Discrimination may motivate the former to start their own businesses, as they may feel that discrimination is a barrier to finding suitable employment that fits their skills and qualifications (Levie, 2007).

In contrast, pull factors contributing to immigrant entrepreneurship are those that make selfemployment appear more attractive than paid employment, such as the potential to obtain a higher income (particularly in the long run), alongside greater independence and a more flexible work schedule (e.g., Shinnar and Young, 2008). Basu and Goswami (1999) discovered that the higher social standing in the community that entrepreneurs often receive may also act as a significant pull factor. Pull factors are closely linked to 'opportunity' entrepreneurship (Reynolds et al., 2002; Sternberg et al., 2006; Block and Wagner, 2010). Opportunity entrepreneurship reflects new business ventures which arise from the identification of an opportunity to be exploited, for example where a gap in an import market is identified. Hence, in general, necessity entrepreneurship is largely driven by push factors while opportunity entrepreneurship is largely driven by pull factors.

Further factors that boost migrant entrepreneurship are: (1) knowing someone who has successfully run a business and can act as a role model (a form of social capital); (2) a perception of new market opportunities (opportunistic entrepreneurship); (3) a positive attitude toward new business activity; and (4) easy acquisition of resources for the new business venture (which may in part be facilitated by social capital). Additionally, migrants may view the world differently and see new market opportunities that locals have missed, owing to their unique cultural backgrounds and skills developed in another country (Levie, 2007).

Migrants may also be less risk averse and this attitude to risk taking may be transferred to a host country which offers a new environment and a chance to start afresh. Entrepreneurship is a form of experimentation that has a U-shaped density function of returns: a great chance of failure, low average returns and a chance to make a very large return (Kerr et al., 2014). Hence we would expect the incidence of entrepreneurship to be somewhat greater among migrants than among the native born given that migrants are often less risk averse, more optimistic and also attach utility to greater freedom and independence in the host country than in the country they left behind. All these migrant characteristics coincide with the attributes that define entrepreneurship (e.g., Åstebro et al., 2014). Acs and Szerb (2007) find that a higher propensity for migrants to engage in entrepreneurship remains once 
basic demographic variables and differences in opportunity perception, risk propensity and experience are controlled for.

An important factor influencing migrant entrepreneurship is the ability to acquire the necessary resources to undertake a new venture. If potential migrant entrepreneurs are unable to access funds from their family or members of their ethnic group, then they will have to rely on banks and other lending institutions (Ibrahim and Galt, 2011). Compared with native born entrepreneurs, immigrants are at a disadvantage in financial markets because they may be unfamiliar with how business is done in the host country and the regulations and processes involved for starting a new business. They may also face discrimination in accessing finance. These barriers are especially pronounced for new immigrants who usually have little collateral to offer formal financial institutions and who have not yet established the networks within their ethnic group to access pooled ethnic resources. However, there is no consensus that ethnicity is an important determinant of migrant entrepreneurship. The impact of ethnicity on entrepreneurship is likely to depend on the ethnic composition of the migrant population and on host country institutional factors. For example, Ohlsson et al. (2012) find that ethnic context and the economic environment play only a minor role in explaining differences in self-employment between migrants and the native born in Sweden.

Necessity and opportunity entrepreneurship are likely to interact with migrant skills. Low-skilled migrants may have no alternative but to start a business because of a lack of other employment opportunities (necessity entrepreneurship). Ventures run by migrants with few skills are often small due to their limited access to financial assets. However, such ventures may provide low cost services to the native population. In turn, this can enhance economic growth through second order effects (OECD, 2010). Small businesses can collectively generate substantial economic activity, especially in areas that may otherwise be experiencing demographic or economic decline.

In contrast, high-skilled migrants are more likely to create firms that are somewhat larger and can become high-growth ventures, in part because they have access to sufficient resources to exploit entrepreneurship opportunities. This may result in overall job growth and increased innovation (OECD, 2010). Baycan-Levent and Nijkamp (2009) argue that the entrepreneurial behaviour of numerous migrant groups has led to a new phenomenon known as 'migrant entrepreneurship' or 'ethnic entrepreneurship' and that this has become one of the driving forces for economic growth.

For both migrants and the native born, entrepreneurship can be affected by social capital. Social capital is the stock of a person's linkages with other actors along which information flows and exchanges are made (e.g., Roskruge, 2013). The information obtained through social networks can be used to improve a person's standard of living and productivity (Roskruge et al, 2012). While this creates an incentive for an individual to invest in social capital, Putnam (2007) argues that social capital is also a 
public good that generates positive externalities for others. Casson and Della (2007) argue that social capital has a much wider impact than most scholars appreciate, with one such impact being the facilitation of entrepreneurship.

It is important to distinguish between productive social capital, which benefits business directly, versus the social capital reflected in civil society and social cohesion (e.g., Putnam, 1995), which benefits business indirectly. Business-focused social capital, such as the proxies used in Westlund et al. (2014), is likely to provide a clearer impetus to become an entrepreneur.

Several studies have examined how the impact of social capital on entrepreneurship differs across migrant groups. Turkina and Thai (2013) find that social factors help to explain the varying prevalence of entrepreneurship across groups, including migrants. Similarly, Shane and Venkataraman (2000) suggest that entrepreneurship arises out of "the nexus of two phenomena: the presence of lucrative opportunities and the presence of enterprising individuals" (p.218). Baron and Markman (2003) argue that social capital can assist entrepreneurs in accessing vital contacts such as venture capitalists and potential customers. Additionally, migrant entrepreneurs create their own social capital through connections with other immigrants and the resources generated from these contacts (Kloosterman and Rath, 2001).

Social capital has an on-going role, not only in the start-up of a business but also in its early life, through the ways in which it can assist in managing relations with customers, suppliers and employees (Westlund and Bolton, 2003). Galbraith et al. (2007) suggest a model of ethnic entrepreneurial conduct in which the potential entrepreneurs enter "an ethnic community seeking employment, then accumulate resources and progress into a start-up phase that relies primarily upon intra-ethnic business ties which in turn matures into a third stage of extra-ethnic market expansion" (pg. 44). However, Woolcock (1998) suggests there is a thin line between utilizing contacts and relying on the social networks of an ethnic group, which can be both a hindrance and help. This is further confirmed by Nijkamp et al. (2010) who identify downsides to migrants relying on social capital, given that it may discourage an outreach strategy to capture wider markets. Finally, Jones and Ram (2011) argue that entrepreneurs may be unwilling to build social capital that benefits the community, as they do not want to dilute their control and market position by sharing resources and information.

There are two different types of social capital used by migrants that may be of benefit to migrants to a host country: bonding and bridging (Eraydin et al., 2010). Bonding social capital is the term used to describe social capital which is formed within groups of similar people, e.g., amongst migrants from the same home country or individuals from the same workplace. In contrast, bridging social capital is the term used to describe social capital networks which are formed between people of different groups. For example, where a migrant who is part of a home country network and also a 
workplace network, that migrant acts as a bridge between the two networks (Kleinhans et al., 2007). Davidsson and Honig (2003) found that bridging social capital becomes increasingly important as the new business develops. Bridging social capital provides more resources and wider contacts in different social circles than bonding social capital. The difference between bridging and bonding social capital is important in our entrepreneurship context. Depending on the focus of a migrant's new venture, either bonding or bridging social capital may be comparatively more important. For example, bonding will be important where the potential market is within the ethnic community. Bridging is important for national and international markets.

It is unclear whether these literature findings can be applied to New Zealand. At the national level, Cruickshank and Rolland (2006) argue that New Zealanders are traditionally highly entrepreneurial. New Zealand is a small island nation of only about 4.5 million people who are highly urbanised and predominantly living in five large cities (with Auckland alone accounting for one third of the total population). This ensures that people are relatively closely networked and are likely to have, in network terms, few degrees of separation from other people. Below the national level, there has been little econometric research into immigrant entrepreneurship in New Zealand. Wang and Maani (2014) focused on the location choice of immigrants and the effect this has on ethnic entrepreneurship defined by self-employment. Their key idea is that the behaviour of individual immigrant entrepreneurs is influenced by that of others of their ethnic group in the same city, i.e. a kind of spatial lag. They find that this network effect has a positive impact on the self-employment decision. The benefits of migrant entrepreneurship in New Zealand were explored by De Bruin (1996) who finds that a community entrepreneurship initiative can create direct employment opportunities that can offset ethnic unemployment in New Zealand.

We are not aware of other research that has applied social capital concepts to ethnic or migrant entrepreneurship in the New Zealand context. This may be partially due to difficulties in measuring social capital and also due to a previous lack of suitable micro-data, with the 1996 World Values Survey one of the few data sources suitable for such research prior to the 2008 General Social Survey. Roskruge et al. (2012) argue that it is reasonable to believe that the cultural differences among New Zealand's population will lead to ethnic variations in social capital formation. In terms of the type of social capital favoured by migrants in New Zealand, Roskruge (2013) found that migrants are more prone to engage in bonding activities while the native born are more likely to participate in bridging activities.

In conclusion, although there are extensive international literatures on immigrant entrepreneurship and on the use of social capital by entrepreneurs, there appears to be a gap in the literature regarding the relationship between these two phenomena from an economic perspective. 
There also does not appear to be consensus as to whether social capital is beneficial to entrepreneurs. Hence in this paper we use econometric analysis to investigate how social capital used by migrant entrepreneurs may differ from how it is used by New Zealand born entrepreneurs. Furthermore, our research contributes to the debate on social capital by providing empirical evidence as to whether social capital is an influential variable when engaging in new business activity. Finally, we explore to what extent social capital contributes to a discrepancy in economic standard of living between migrant and native entrepreneurs.

\section{Data and Methodology}

We use pooled cross-sectional survey data collected from the 2008, 2010 and 2012 waves of the NZGSS. The NZGSS is an official survey of social outcomes in New Zealand conducted biennially by Statistics New Zealand. The survey covers information on areas specifically pertaining to the issues of concern in the present study: culture and identity, income, type of employment and social connectedness (a measure of social capital). The 2008, 2010, and 2012 basic NZGSS CURFs include 8,721, 8,550 and 8,462 individual responses respectively. There are therefore a total of 25,733 observations in the merged dataset.

The NZGSS collects information at the household and at the individual level. Statistics New Zealand recruits participating households by means of a sample selection method that selects 1,200 primary sampling units (PSU) from the Household Survey Frame, which is then narrowed down to eligible households from the selected PSUs. Eligible individuals (aged over 15 years) are randomly selected to complete the individual component of the NZGSS from each of the participating households.

Migrant entrepreneurs are defined as people receiving their primary source of income from either self-employment or from running their own business with employees. The economic standard of living of entrepreneurs is measured by the Economic Living Standards Index Short Form (ELSI-SF) and by their personal income. ELSI-SF is a reduced form of the ELSI index developed by the Ministry of Social Development. It is a measure of New Zealand living standards that includes non-income indicators of the material standard of living and hardship (Perry, 2009). Although it is clear that income is strongly correlated with the standard of living, income is only one factor that affects the ELSI and the ELSI-SF scores.

ELSI-SF contains various items that are indicative of: a household being able to meet basic needs or not (e.g., having to postpone medical treatment due to cost); the ability to purchase luxuries (e.g., overseas holidays); financial or accommodation problems (cannot pay bills, damp house); the ability to purchase children's basic items of consumption (e.g., raincoats) in the case of families with 
children (Jensen et al., 2006). To include the respondents' self-perception alongside objective items in the ELSI scale, three self-rated responses are included. These cover: adequacy of income to meet every day needs, satisfaction with the standard of living, and the standard of living self-rating. The variables are calibrated to provide a basis for interpreting the ELSI-SF scale, which yields a score between 0-31 (compared to a scale of 0-60 for the full length ELSI). The range of scores in the ELSI long-form were broken into seven intervals for ease of use, with severe hardship for level 1 through to very good living standards for level 7 (see Table A1 in the Appendix).

The items that make up the ELSI-SF scale are: (1) ownership restrictions (people cannot afford to own what they would like) for a range of items from basic items to luxury goods; (2) social participation restrictions (social activities respondents were prevented from engaging in because of the cost; these range again from basics such as a haircut to more luxury items such as overseas holidays); and (3) economising behaviour (when facing financial difficulty people will limit or reduce spending on certain items; see Jensen et al, 2006).

Restricting the data to a sub-sample of those who are labour force participants results in 15,541 individual observations (60.4 percent of the full sample), with 3,180 (20 percent) of this sample reporting to obtain income from being self-employed or from running a business. Regressions are done for all labour force participants, for the native born only, and for migrants only.

All regressions were run in Stata 11.2. For each regression, a standard set of control variables are included, consisting of: (1) demographic characteristics (age, sex, children, etc.); (2) human capital and employment variables (highest education qualification, occupation, etc.); (3) migrant and ethnicity variables (country of birth grouped in global regions, years in New Zealand, etc.); (4) geographical variables (urban, rural, etc.); and (5) dummy variables signalling the year of the survey. ${ }^{3}$

To measure social capital, five proxies are selected. They are: (1) access to community facilities; (2) feelings of safety within the community; (3) whether an individual can get help from others in times of need; (4) feelings of social inclusion rather than isolation; (5) active volunteer work; and (6) participation in a community activity. One drawback of these measures is that they proxy for social capital in a very broad social cohesion / civil society sense, rather than having a specific relationship to business activity. While the literature review identified a theoretical relationship between civil measures of social capital and entrepreneurship, we expect the strength of these relationships to be weaker than what might be observed with business-focused social capital measures. Regrettably the latter measures are not available in our data.

Our first regression uses our full range of independent variables to capture the characteristics that influence whether the respondent is an entrepreneur. Given that the dependent variable is binary

\footnotetext{
${ }^{3}$ See Table $A 2$ in the Appendix for more details.
} 
in nature, a standard logit regression model is utilised. ${ }^{4}$ The second set of regressions identifies the extent to which the determinants of the economic standard of living differ between New Zealand and foreign-born entrepreneurs. As noted earlier, the economic standard of living is proxied by the seven point classification of ELSI-SF. Given the nature of ELSI-SF, the ordered logit model was used to examine the determinants of ELSI-SF. Thirdly, personal income gives an alternative indication of the material quality of life for both migrants and New Zealand born groups. Massari (2005) argues that, since wellbeing is not directly observable, many studies use data on income as a proxy measure for the standard of living. Moreover, using income permits comparisons across time and different countries (Courtois, 2009, p. 12). Hence, the results from this Mincerian earnings regression can easily be compared with both past and future international studies.

\section{Results}

\subsection{Determinants of entrepreneurship}

Table 1 reports logit regressions of the prevalence of entrepreneurship as defined as those obtaining income from self-employment or from running a business. A full description of the variables can be found in the Appendix. The reported results are robust across a range of specifications. ${ }^{5}$ The first column uses a pooled sample of migrants and native-born workers. ${ }^{6}$ Columns (2) and (3) test for heterogeneity between these groups by estimating logit models for the native born and for the foreign born separately.

Table 1 about here

\section{Social capital}

The most robust result is a strong partial correlation between the prevalence of entrepreneurship and volunteering (ks_vol). Those who engage in volunteering work have a higher propensity to be an entrepreneur. Social networks established by volunteering and the positive reputation from volunteer work may make entrepreneurs more confident of the likely success of new business ventures in the

\footnotetext{
${ }^{4}$ Logit and probit nonlinear regression models are the two models that are commonly applied to binary response situations, although the linear probability model (LPM, which is linear regression of a variable with outcomes restricted to 0 and 1 ) is also popular and quite adequate for large samples and common outcomes. Manski and Xie (1989) remind us that the results from logit models are mostly very similar to those from the corresponding probit models. Hence, the decision between logit and probit regression is largely down to the researcher's preference.

${ }^{5}$ Alternative specifications did not yield important additional insights. Details are available from the authors upon request.

${ }^{6}$ All variables are defined for both immigrants and the native born. All "years since migration" variables have the value 0 for all native born observations.
} 
local community. Hence economic and social entrepreneurship reinforce each other (Westlund, 2011). Interestingly, the coefficient is almost identical for the native born and migrants.

There are three social capital factors that operate differently between the migrant and native born populations: feelings of safety (ks_safe), feeling socially included (ks_included) and taking part in community and professional activities (ks_part). Feeling safe in their neighbourhood has a statistically significant and positive effect on survey respondents being entrepreneurs, but this is only the case for the native born. Similarly, taking part in a group or organizational activity (not as a volunteer) boosts the probability of entrepreneurship among the native born. For migrants, respondents who felt included in the community, i.e. not isolated, the probability of entrepreneurship is lower, possibly because of greater employment opportunities within their ethnic community reducing the need for necessity entrepreneurship. Adequate access to local facilities (geo_facilities) and the availability of help in time of need (ks_help) do not have a statistically significant association with the prevalence of entrepreneurship.

\section{Human capital}

Being on fixed-term contracts as employees (emp_fixt), or having a permanent job (emp_perm), is clearly unlikely to give individuals an opportunity to practice entrepreneurship and therefore strongly reduces the likelihood of income from self-employment or running a business. This is true for both migrants and the native born. The years of schooling variable (edu_yos) has a positive association with entrepreneurship that is significant at the 1 percent level for the native born and at the 10 percent level for the foreign born. More human capital stimulates opportunity entrepreneurship. However, foreign education among the New Zealand born (most likely to have been tertiary education) is less likely to lead to entrepreneurship. This may well be because these workers have a high return to that foreign education as employees in the New Zealand labour market (Poot and Roskruge, 2013). For immigrants, education in New Zealand (edu_os=0) lowers the likelihood of immigrants being self-employed or running a business. Working part-time (emp_part) lowers the likelihood of income from selfemployment or running a business, but the effect is only statistically significant for the native born. In contrast, holding a trade certificate (trade) is positively related to entrepreneurship among the native born group. A negative attitude to education (edu_negatt) and the opposite, possessing a postgraduate qualification (postgrad), are both statistically insignificant variables. 


\section{Other variables}

All demographic variables are all statistically significant at the 1 percent level for both native and migrant entrepreneurs, except having dependent children (demo_child). Males (demo_male) are more likely to be entrepreneurs than females. This gender effect is much stronger among migrants than among the native born. The age effect is non-linear and concave, indicating that the prevalence of entrepreneurship increases with age, but at a declining rate. The coefficient of demo_age is smaller for migrants than for natives. Having a partner (demo_partner) is also an important predictor of entrepreneurship. This variable is more influential for migrants than the native born. This is in line with the international literature which finds that female partners of ethnic entrepreneurs tend to provide vital, albeit often unacknowledged, work in the business.

With respect to ethnicity, Table 1 reports that Māori (eth_amori) are less likely to obtain revenue from self-employment or running a business than non-Māori. This is also true for migrants born in the Pacific Islands (bp_pacifica) or born in New Zealand, but belonging to the Pacifica ethnic group (bp_nz_pacifica). Amid the other birthplace variables, only migrants from western countries (bp_western) have a statistically significant higher probability of entrepreneurship. Migrants born in western cultures may find it easier to engage in entrepreneurial behaviour in New Zealand than other migrants. Although New Zealand is culturally diverse, with one quarter of the population foreign born and Māori accounting for close to one fifth of the New Zealand born, western culture still dominates in business. The coefficients of the years since migration variables (mig_ysm) show that the prevalence of migrant entrepreneurship increases with years in New Zealand, up to 10 years of residence (the reference level is 20 years of residence or more).

The rural variable (geo_rural) has a positive coefficient and is significant at the 1 percent level for all groups. Respondents from rural areas are relatively more likely to engage in self-employment or run a business. Most of these rural entrepreneurs are farmers. As migrants tend to be disproportionally located in cities, the geo_rural coefficient for migrants is smaller than for the New Zealand born. Perhaps surprisingly, an Auckland location (geo_akl) had a statistically significant - but negative influence on migrant entrepreneurship, all else being equal. Migrants' opportunities for income as paid employees are much better in New Zealand's largest agglomeration, thereby reducing the need for necessity entrepreneurship.

\subsection{Economic living standards of entrepreneurs}

We now turn to ordered logit regressions that suggest determinants of economic living standards (as measured by ELSI-SF) amongst entrepreneurs. The results are reported in Table 2. 
Table 2 about here

\section{Social capital}

The social capital variables that relate to the presence of facilities, feelings of safety, access to help and being included (not feeling isolated) are all significantly and positively related to ELSI-SF at the 1 percent level. Behavioural social capital factors (volunteering and participation in social activities) are statistically insignificant. The former social capital variables are indicative of the strength of networks. Stronger networks are associated with a higher ELSIE-SF score, i.e. a higher living standard. Interestingly, these networks-related social capital variables are of roughly equal importance for both migrant and native-born entrepreneurs. ${ }^{7}$

\section{Human capital}

Not surprisingly, part-time employment has a significantly negative effect on the economic living standards for both migrant and native-born entrepreneurs. This can be attributed to such entrepreneurs not being able to commit to full-time work on their business, which is where they would need to be spending their time and energy to turn their firm into a major asset. The negative part-time work effect is much stronger for migrants. Years of schooling exhibit a statistically significant positive effect on living standards for all groups, which is in line with the huge literature on the positive returns - in terms of economic living standards - to additional years of education. Entrepreneurs who describe themselves as doing managerial and professional work have higher living standards than those in other occupations. This is the case for both migrants and the native born.

\section{Other variables}

Having a partner is associated with higher economic living standards, but only for the native born. The positive effect of a partner on economic living standards is widely recognised in the literature (see e.g., Vespa and Painter, 2011). Moreover, there is negative relationship between having children and ELSI-SF scores of entrepreneurs, with similar coefficient for both migrants and the native born. The inverse relationship between fertility and the economic standard of living is a fundamental finding in population economics (e.g., Poot and Siegers, 1992, in the New Zealand context). However, age and gender of the entrepreneur are mostly not statistically significant in these living standards regressions.

Migrant entrepreneurs born in Pacific countries (bp_pacifica), born in the Pacific but with Asian ethnic identity (bp_apac, predominantly Fijian Indians), those born in the Middle East, Latin America or Africa (bp_melaa) and those born in Asia (bp_asia) experience statistically significantly lower ELSI-SF scores. The western, ethnically European, population has generally a higher standard of living than

\footnotetext{
${ }^{7}$ This can be confirmed by formal hypothesis testing of the equality of the regression coefficients.
} 
other population groups, although the matter is more complex than can be investigated here. There is evidence of some discrimination in the labour market among non-European groups (Daldy et al., 2013). The geographic variables related to ELSI-SF are mostly insignificant for both native born and migrant entrepreneurs. Reported living standards scores were lower in the 2010 and 2012 surveys than in the 2008 survey, but only for native born entrepreneurs. This is likely to be due to the 2008 Global Financial Crisis which may have subsequently impacted more on native-born entrepreneurs, with immigrants in New Zealand being on average higher skilled than the native born.

\subsection{Income of entrepreneurs}

Table 3 reports the results for Mincerian OLS regressions regarding the determinants of the natural logarithm of personal income of entrepreneurs.

Table 3 about here

\section{Social capital}

In contrast to human capital, only a few social capital variables are related to entrepreneurial income. Participation in activities (ks_part) is significant at the 5 percent level for migrant entrepreneurs, while feelings of safety (ks_safe) and inclusion (ks_included) are weakly significant for native born entrepreneurs. It can be argued that the causality runs here in the opposite direction: greater income facilitates greater participation in community activity as well as residential location in safer and more inclusive areas. However, assessing the causal nature of this interrelationship, e.g., by instrumental variables, remains a topic for future research. For both groups there is no evidence that volunteering (ks_vol), access to help (ks_help) and the accessibility of public facilities (geo_facilities) are related to income.

\section{Human capital}

As is the case with earnings regressions generally, most of the human capital variables have a significant relationship with personal income. Not surprisingly, attitude to education was not related to personal income given that current income is a function of past investment in human capital not intentions with respect to future investment. Years of schooling are a significant determinant at the 1 percent level for native-born entrepreneurs and at the 10 percent level for migrant entrepreneurs. The rate of return to an additional year of education is 4.4 percent for native-born entrepreneurs and 3.0 percent for foreign born entrepreneurs. 
The coefficients of the occupational dummies are all as expected, with the highest coefficients observed for self-employed professional workers or professionals running a business, e.g., doctors and dentists in private practice. Interestingly, these coefficients are much larger for migrants than for the native born. This is consistent with the points-based selection system of immigrants in New Zealand, which gives much weight to professional qualifications and skills.

\section{Other variables}

The regressions show the usual concave age earnings profile. The gender effect is also as expected. Male entrepreneurs earn, ceteris paribus, about 30 percent more than female entrepreneurs if they are native born and 40 percent more if they are foreign born. Having a partner and/or having children does not have a significant relationship with personal income for both groups of entrepreneurs.

The results of the income regressions with respect to the migration and ethnicity variables are fairly consistent with those of standard of living regressions. There is a significant negative relationship with personal income for Asian entrepreneurs, either those born in Asia (bp_asia) or those born in the Pacific (bp_apac). This suggests that migrants from these origins may be pushed into self-employment, or necessity entrepreneurship, rather than being attracted to start their own business due to an identified opportunity. Self-reported workplace discrimination is low on average, but relatively higher among Asian migrants in New Zealand (e.g., Daldy et al., 2013).

Migrant entrepreneurs who have been in New Zealand less than five years have statistically significant lower income (about 25 percent less) than those who have been longer in the country (see also Stillman and Maré, 2009). Native entrepreneurs in New Zealand's largest agglomeration, Auckland (which accounts for roughly one third of the country's population of 4.5 million), earn about 13 percent more than in other parts of the country. For migrants, the relative nominal (there is no adjustment for inter-urban differences in the cost of living) income gain in the Auckland agglomeration is even greater (15 percent), but the coefficient is only significant at the 10 percent level. Income of migrant entrepreneurs in the Canterbury region is 39 percent lower. The Global Financial Crisis and the large earthquake in Christchurch in February 2011 may have had a relatively large impact on this region. On average, though, the year of survey dummies are statistically insignificant. Finally, after controlling for the biggest cities, the other geographical dummies (main urban areas and rural areas are statistically insignificant. 


\section{Final reflections}

Comparing the three sets of regressions, we find that the association between social capital variables and entrepreneurship prevalence and returns are rather different between native born and immigrants. The perception of safety in the local neighbourhood has a positive impact on both the incidence and payoff of entrepreneurship, but this effect is weaker or absent among migrants. For the latter, trust in others in their own migrant community may be more important than trust in others in their city generally. We should also note that the positive effect we observe of volunteering on the prevalence of migrant and native-born entrepreneurship may not be causal, but reflect an unmeasured personal trait that positively impacts on both.

Although we cannot formerly test the strength of a causal link from volunteering to entrepreneurship, the existence of such a link is plausible because of the opportunity it provides to expand the respondents' networks and contacts through creating interactions with people outside the individual's typical social circle. Furthermore, the chance to develop skills that can be transferred to their own firm is especially important for migrants, who often find it difficult to obtain jobs where they would normally develop these skills, such as project management and budgeting (Alleyne, 2007). An additional benefit of volunteering for migrants can be the ability to become familiar with the local community and understand how it operates, which allows them to integrate so that they can confidently take advantage of any market opportunities.

However, our regressions do not provide evidence that volunteering "pays off", in that the living standards or incomes of entrepreneurs who engage in volunteering are higher than those of entrepreneurs who do not. Instead, strong networks do appear to pay off in the sense that entrepreneurs who feel socially included have higher living standards.

Generally, one explanation for the mixed performance of our social capital proxies in predicting entrepreneurship and its outcomes may be the focus on 'social cohesion', i.e. civil social capital, rather than business-focused social capital which would theoretically have a more direct relationship to business outcomes (e.g., Westlund et al., 2014). Our focus on civil social capital was necessitated by the data. Additionally, the likelihood of becoming an entrepreneur and the resulting outcomes are partially determined by contextual factors beyond the characteristics of the individual that we cannot observe in our data. As Shane and Venkataraman (2000) noted, entrepreneurship arises when resourceful and innovative individuals connect with opportunities presented by the market. It is therefore likely that the opportunities presented by market forces have a greater ability to explain the incidence of migrant entrepreneurship than social capital variables do. It may also be that the literature on migrant entrepreneurship places too much emphasis on the social networks used by immigrants. This idea corroborates with the concept outlined in Van Der Leun and Kloosterman (1999) who argue that in 
order to determine the likelihood of engaging in entrepreneurship, researchers need to account not only for their embeddedness in social networks, but also for the wider socio-economic environment of the host country. Our present pooled cross-sectional data is not suited to testing such ideas. Instead, the emergence of the Integrated Data Infrastructure (IDI) in New Zealand, which provides longitudinal microdata from a mixture of public surveys and administrative systems, offers great promise for future in-depth study of entrepreneurship (Statistics New Zealand, 2014).

There appears to be some heterogeneity in the results with respect to birthplace regions, with MELAA, Asian and Pacific countries having the relatively most adverse outcomes. Meanwhile, migrants from Western countries have a greater propensity to engage in entrepreneurial behaviour and have the greatest economic standard of living. This result may be explained by the fact that New Zealand shares a similar culture with other Western countries which makes taking advantage of opportunities easier for migrants with European ethnicity, as they may be more familiar with how New Zealand businesses and the institutional system operate, and how to access funding and other resources.

Interestingly, we find a gender effect in entrepreneurship prevalence and income but not in the living standards regressions. Being male increases entrepreneurship prevalence and relates to higher personal incomes. There are several explanations for this phenomenon in which native and migrant women share many of the same characteristics (Baycan-Levent, 2010). The issue of gender in entrepreneurship constitutes a wide branch of literature, but we note three general points here. Firstly, the time taken off work to raise children often adversely affects the career and salary progression for females. Secondly, men are more likely to engage in risky behaviour than women (Harris et al., 2006) which may contribute to their higher probability of becoming an entrepreneur. Thirdly, females often perceive the entrepreneurial area in less favourable light than their male counterparts and these perceptions can influence their behaviour (Langowitz and Minniti, 2007).

This study has several shortcomings, including the measurement of entrepreneurial income. The reported income covers any form of income and not just income derived from self-employment or running a business. Additionally, to test for differences in risk attitudes between entrepreneurs and employees, it may be useful to contrast the entire distribution of income for the two groups (see e.g., evidence from Denmark by Åstebro et al., 2014).

Our research can be further enhanced by including productive and network social capital variables which are may be sourced from the Time Use Survey or the Social Indicators Survey from Statistics New Zealand. Other proxies of the performance of entrepreneurs, for instance patents registered (in the applicable sectors), could be added to the analysis. Future research can also investigate the demography and life course of the business start-ups and measure the success of entrepreneurial firms, and the factors that influence this success, with a particular focus on migrant 
businesses. As noted above, our available data did not contain some preferred 'business focused' social capital measures. Clearly, a longitudinal framework (for example, as provided by New Zealand's IDI) and the construction of exogenous instruments that enable the assessment of causal effects are promising directions for future empirical research. Such research may contribute to a better understanding of how immigration policy can enhance social cohesion, entrepreneurship, and stronger economic growth.

\section{References}

Acs, Z.J., and Szerb, L. (2007). Entrepreneurship, economic growth and public policy. Small Business Economics, 28(2), 109-122.

Alleyne, S. (2007). Volunteering helps you, too. Black Enterprise, 37(11), 74.

Åstebro, T., Herz, H., Nanda, R. and Weber, R.A. (2014). Seeking the roots of entrepreneurship: insights from behavioural economics. Journal of Economic Perspectives, 28(3), 49-70.

Baron, R.A., and Markman, G.D. (2003). Beyond social capital: The role of entrepreneurs' social competence in their financial success. Journal of Business Venturing, 18(1), 41-60.

Basu, A., and Goswami, A. (1999). South Asian entrepreneurship in Great Britain: factors influencing growth. International Journal of Entrepreneurial Behaviour and Research, 5(5), 251-275.

Baycan-Levent, T. (2010). Migrant women entrepreneurship in OECD countries. In: Open for Business: Migrant Entrepreneurship in OECD Countries, p.227-254. Paris: OECD Publishing.

Baycan-Levent, T., and Nijkamp, P. (2009). Characteristics of migrant entrepreneurship in Europe. Entrepreneurship and Regional Development, 21(4), 375-397.

Block, J. H., and Wagner, M. (2010). Necessity and opportunity entrepreneurs in Germany: Characteristics and earnings differentials. Schmalenbach Business Review, 62, 154-174.

Casson, M., and Della, G.M. (2007). Entrepreneurship and social capital: Analysing the impact of social networks on entrepreneurial activity from a rational action perspective. International Small Business Journal, 25(3), 220-244.

Constant, A., and Zimmermann, K.F. (2006). The making of entrepreneurs in Germany: Are native men and immigrants alike? Small Business Economics, 26(3), 279-300.

Courtois, R. (2009). Measuring Quality of Life. Region Focus, 13(3), 12-15.

Cruickshank, P., and Rolland, D. (2006). Entrepreneurial success through networks and social capital: Exploratory considerations from GEM research in New Zealand, Journal of Small Business and Entrepreneurship, 19(1), 63-80.

Daldy, B., Poot, J., and Roskruge, M. (2013). Perception of workplace discrimination among immigrants and native born New Zealanders. Australian Journal of Labour Economics, 16(1), 137-154.

Davidsson, P., and Honig, B. (2003). The role of social and human capital among nascent entrepreneurs. Journal of Business Venturing, 18(3), 301-331.

De Bruin, A. (1996). From cultural to economic capital: Community employment creation in Otara. Retrieved from http://ojs.victoria.ac.nz/LEW/article/view/962/775

De Carolis, D. M., and Saparito, P. (2006). Social capital, cognition, and entrepreneurial opportunities: A theoretical framework. Entrepreneurship theory and practice, 30(1), 41-56. 
Eraydin, A., Tasan-Kok, T., and Vranken, J. (2010). Diversity matters: Immigrant entrepreneurship and contribution of different forms of social integration in economic performance of cities. European Planning Studies, 18(4), 521-543.

Fairlie, R.W. and Lofstrom, M. (2015). Immigration and entrepreneurship. In: B.R. Chiswick and P.W. Miller (eds) Handbook of the Economics of International Migration, Volume 1B. Amsterdam: North-Holland Elsevier.

Galbraith, C.S., Rodriguez, C.L., and Stiles, C.H., (2007). Social capital as a club good: The case of ethnic communities and entrepreneurship. Journal of Enterprising Communities, 1(1), 38-53.

Harris, C., Jenkins, M., and Glaser, D. (2006). Gender differences in risk assessment: Why do women take fewer risks than men? Judgment and Decision Making Journal, 1(1), 48-63.

Ibrahim, G., and Galt, V. (2011). Explaining ethnic entrepreneurship: An evolutionary economics approach. International Business Review, 20(6), 607-613.

Jensen, J., Krishnana, V., Hodgson, R., Sathiyandra, S.G., Templeton, R., Jones, D., Goldstein-Hawes, R., and Beynon, P. (2006). New Zealand Living Standards 2004. Retrieved from http://www.msd.govt.nz/documents/about-msd-and-our-work/publicationsresources/monitoring/living-standards-report.pdf.

Jones, T., and Ram, M. (2011). Ethnic entrepreneurs and urban regeneration. In: A. Southern (ed.) Enterprise, Deprivation and Social exclusion: The Role of Small Business in Addressing Social and Economic Inequalities. New York: Routledge.

Kerr, W.R., Nanda, R. and Rhodes-Kropf, M. (2014). Entrepreneurship as experimentation. Journal of Economic Perspectives, 28(3), 25-48.

Kleinhans, R., Priemus, H., and Engbersen, G. (2007). Understanding social capital in recently restructured urban neighbourhoods: Two case studies in Rotterdam. Urban Studies, 44(5-6), 1069-1091.

Kloosterman, R., and Rath, J. (2001). Immigrant entrepreneurs in advanced economies: mixed embeddedness further explored. Journal of Ethnic and Migration Studies, 27(2), 189-201.

Langowitz, N., and Minniti, M. (2007). The entrepreneurial propensity of women. Entrepreneurship Theory and Practice, 31(3), 341-364

Levie, J. (2007). Immigration, in-migration, ethnicity and entrepreneurship in the United Kingdom. Small Business Economics, 28(2/3), 143-169.

Manski, C.F., and Xie, Y. (1989). The logit model and response-based samples. Sociological Methods and Research, 17(3), 283-302.

Massari, R. (2005). A measure of welfare based on permanent income hypothesis: An application on Italian households budgets. Giornale Degli Economisti e Annali Di Economia, 64(1), 55-91.

Nijkamp, P., Sahin, M., and Baycan-Levent, T. (2010). Migrant entrepreneurship and new urban economic opportunities: Identification of critical success factors by means of qualitative pattern recognition analysis. Tijdschrift Voor Economische En Sociale Geografie, 101(4), 371-391.

OECD (2010). Open for business: Migrant Entrepreneurship in OECD Countries. Washington: Organisation for Economic Cooperation and Development (OECD).

Ohlsson, H., Broomé, P. and Bevelander, P. (2012). Self-employment of immigrants and natives in Sweden - a multilevel analysis. Entrepreneurship \& Regional Development, 25(5-6), 405-423.

Pendakur, R., and Mata, F. (1999). Immigration, labor force integration and the pursuit of selfemployment. International Migration Review, 33(2), 378-402. 
Perry, B. (2009). Non-income measures of material standard of living and hardship: first results from the 2008 New Zealand Living Standards Survey, with international comparisons. Working Paper No. 01/09. Ministry of Social Development.

Poot, J. and Roskruge, M. (2013). Internationalisation of education and returns in the labour market. Studies in Regional Science, 43(1): 61-78.

Poot, J. and Siegers, J.J. (1992). An economic analysis of fertility and female labour force participation in New Zealand. New Zealand Economic Papers, 26(2): 219-248.

Putnam, R.D. (2007). E pluribus unum: Diversity and community in the twenty-first century - The 2006 Johan Skytte Prize Lecture. Scandinavian Political Studies, 30(2), 137-174.

Putnam, R.D., (1995). Bowling Alone: America's Declining Social Capital. Journal of Democracy, 6(1), 6578

Reynolds, P. D.,Camp, S. M., Bygrave, W. D., Autio, E. and M. Hay, (2002). Global Entrepreneurship Monitor. 2001 Executive Report, Babson College, London Business School

Roskruge, M. (2013). Selected Econometric Models of Social Capital Formation in New Zealand. Doctoral dissertation, University of Waikato, New Zealand.

Roskruge, M., Grimes, A., McCann, P., and Poot, J. (2012). Social capital and regional social infrastructure investment: Evidence from New Zealand. International Regional Science Review, 35(1), 3-25.

Sahin, K., and Ilhan-Nas, T. (2011). International ethnic entrepreneurship: Antecedents, outcomes and environmental context. International Business Review, 20(6), 614-626.

Sequeira, J.M., and Rasheed, A.A. (2006). Start-up and growth of immigrant small businesses: the impact of social and human capital. Journal of Developmental Entrepreneurship, 11(4), 357-375.

Shane, S., and Venkataraman, S. (2000). The promise of entrepreneurship as a field of research. The Academy of Management Review, 25(1), 217-226.

Shinnar, R.S., and Young, C.A. (2008). Hispanic immigrant entrepreneurs in the Las Vegas Metropolitan area: Motivations for entry into outcomes of self-employment. Journal of Small Business Management, 46(2), 242-262.

Statistics New Zealand (2014). Integrated Data Infrastructure. Retrieved from http://www.stats.govt.nz/browse_for_stats/snapshots-of-nz/integrated-data-infrastructure.aspx

Sternberg, R., Brixy, U. and Schlapfner, J. F. (2006). Global Entrepreneurship Monitor. Länderbericht Deutschland 2005. Universität Hannover and IAB.

Stillman, S. and Maré, D.C. (2009). The labour market adjustment of immigrants in New Zealand. Economic Impacts of Immigration Working Paper. Wellington: Department of Labour.

Tolciu, A. (2011). Migrant entrepreneurs and social capital: A revised perspective. International Journal of Entrepreneurial Behaviour \& Research, 17(4), 409-427.

Turkina, E., and Thai, M. (2013). Social capital, networks, trust and immigrant entrepreneurship: A cross-country analysis. Journal of Enterprising Communities: People and Places in the Global Economy, 7(2), 108-124.

Van Der Leun, J., and Kloosterman, R. (1999). Mixed embeddedness: (in)formal economic activities and immigrant businesses in the Netherlands. International Journal of Urban and Regional Research, 23(2), 252-266.

Vespa, J., and Painter, M. A. (2011). Cohabitation history, marriage, and wealth accumulation. Demography, 48(3), 983-1004. 
Wang, X., and Maani, S. (2014). Ethnic capital and self-employment: a spatially autoregressive network approach. IZA Journal of Migration, 3:18.

Westlund, H. (2011). Multidimensional entrepreneurship: theoretical considerations and Swedish empirics. Regional Science Policy \& Practice, 3(3), 199-219.

Westlund, H., and Bolton, R. (2003). Local social capital and entrepreneurship. Small Business Economics, 21(2), 77-113.

Westlund, H., and Gawell, M. (2012). Building social capital for social entrepreneurship. Annals of Public and Cooperative Economics, 83(1), 101-116.

Westlund, H., Larsson, J. P., and Olsson, A. R. (2014). Start-ups and local entrepreneurial social capital in the municipalities of Sweden. Regional studies, 48(6), 974-994.

Woolcock, M. (1998). Social capital and economic development: Toward a theoretical synthesis and policy framework. Theory and Society, 27(2), 151-208. 
Table 1: Logit regression models of entrepreneurship

\begin{tabular}{|c|c|c|c|}
\hline \multirow[t]{2}{*}{ VARIABLES } & $\begin{array}{l}\text { (1) } \\
\text { ent_slfemp }\end{array}$ & $\begin{array}{l}\text { (2) } \\
\text { ent_slfemp }\end{array}$ & $\begin{array}{l}\text { (3) } \\
\text { ent_slfemp }\end{array}$ \\
\hline & Pooled & Native & Migrant \\
\hline \multicolumn{4}{|c|}{ Social capital variables } \\
\hline \multirow[t]{2}{*}{ geo_facilities } & -0.029 & 0.030 & -0.215 \\
\hline & $(0.096)$ & $(0.112)$ & (0.184) \\
\hline \multirow[t]{2}{*}{ ks_safe } & $0.150 * * *$ & $0.027^{* *}$ & 0.039 \\
\hline & $(0.052)$ & $(0.012)$ & $(0.024)$ \\
\hline \multirow[t]{2}{*}{ ks_help } & 0.061 & 0.084 & 0.029 \\
\hline & (0.111) & (0.141) & $(0.185)$ \\
\hline \multirow[t]{2}{*}{ ks_included } & -0.004 & 0.071 & $-0.251 * *$ \\
\hline & $(0.050)$ & $(0.058)$ & $(0.105)$ \\
\hline \multirow[t]{2}{*}{ ks_vol } & $0.406^{* * *}$ & $0.409 * * *$ & $0.392^{* * *}$ \\
\hline & $(0.051)$ & $(0.057)$ & $(0.114)$ \\
\hline \multirow[t]{2}{*}{ ks_part } & $0.109 * *$ & $0.124 * *$ & 0.064 \\
\hline & $(0.049)$ & $(0.056)$ & $(0.110)$ \\
\hline \multicolumn{4}{|c|}{ Human capital variables } \\
\hline \multirow[t]{2}{*}{ edu_negatt } & 0.193 & 0.186 & 0.222 \\
\hline & $(0.136)$ & (0.146) & $(0.383)$ \\
\hline \multirow[t]{2}{*}{ emp_part } & $-0.221 * * *$ & $-0.235^{* * *}$ & -0.190 \\
\hline & $(0.062)$ & $(0.070)$ & $(0.135)$ \\
\hline \multirow[t]{2}{*}{ emp_fixt } & $-1.826 * * *$ & $-1.833 * * *$ & $-1.850 * * *$ \\
\hline & $(0.139)$ & $(0.160)$ & $(0.285)$ \\
\hline \multirow[t]{2}{*}{ emp_perm } & $-2.019 * * *$ & $-2.009 * * *$ & $-2.115^{* * *}$ \\
\hline & $(0.053)$ & $(0.060)$ & $(0.117)$ \\
\hline \multirow[t]{2}{*}{ edu_yos } & $0.063 * * *$ & $0.069 * * *$ & $0.045^{*}$ \\
\hline & $(0.012)$ & $(0.014)$ & $(0.025)$ \\
\hline \multirow[t]{2}{*}{ edu_os } & 0.036 & $-0.745^{* * *}$ & $0.294 * *$ \\
\hline & $(0.078)$ & $(0.371)$ & $(0.132)$ \\
\hline \multirow[t]{2}{*}{ postgrad } & -0.042 & 0.001 & -0.129 \\
\hline & $(0.057)$ & $(0.067)$ & $(0.114)$ \\
\hline \multirow[t]{2}{*}{ trade } & $0.316^{* * *}$ & $0.425^{* * *}$ & -0.090 \\
\hline & $(0.078)$ & $(0.089)$ & (0.179) \\
\hline \multicolumn{4}{|c|}{ Demographic variables } \\
\hline \multirow[t]{2}{*}{ demo_partner } & $0.526 * * *$ & $0.497 * * *$ & $0.638^{* * *}$ \\
\hline & $(0.054)$ & $(0.060)$ & $(0.128)$ \\
\hline \multirow[t]{2}{*}{ demo_age } & $0.166 * * *$ & $0.172 * * *$ & $0.134 * * *$ \\
\hline & $(0.012)$ & $(0.013)$ & $(0.026)$ \\
\hline \multirow[t]{2}{*}{ demo_age2/100 } & $-0.001 * * *$ & $-0.001 * * *$ & $-0.001 * * *$ \\
\hline & $(0.000)$ & $(0.000)$ & $(0.000)$ \\
\hline \multirow[t]{2}{*}{ demo_child } & 0.045 & 0.038 & 0.105 \\
\hline & $(0.055)$ & $(0.063)$ & $(0.116)$ \\
\hline \multirow[t]{2}{*}{ demo_male } & $0.451 * * *$ & $0.394 * * *$ & $0.681^{* * *}$ \\
\hline & $(0.053)$ & $(0.061)$ & $(0.114)$ \\
\hline
\end{tabular}




\begin{tabular}{|c|c|c|c|}
\hline \multirow[t]{2}{*}{ VARIABLES } & $\begin{array}{c}\text { (1) } \\
\text { ent_slfemp }\end{array}$ & $\begin{array}{c}\text { (2) } \\
\text { ent_slfemp }\end{array}$ & $\begin{array}{c}\text { (3) } \\
\text { ent_slfemp }\end{array}$ \\
\hline & Pooled & Native & Migrant \\
\hline \multicolumn{4}{|c|}{ Migrant and ethnicity variables } \\
\hline \multirow[t]{2}{*}{ eth_maori } & $-1.136^{* * *}$ & $-1.128 * * *$ & -0.867 \\
\hline & $(0.129)$ & $(0.131)$ & (1.066) \\
\hline \multirow[t]{2}{*}{ bp_nz_pacifica } & $-0.743 * *$ & $-0.723 * *$ & \\
\hline & $(0.327)$ & $(0.328)$ & \\
\hline \multirow[t]{2}{*}{ bp_western } & -0.038 & & $0.332 * *$ \\
\hline & (0.093) & & $(0.141)$ \\
\hline \multirow[t]{2}{*}{ bp_pacifica } & $-2.176 * * *$ & & $-1.936 * * *$ \\
\hline & $(0.328)$ & & $(0.349)$ \\
\hline \multirow[t]{2}{*}{ bp_apac } & -0.177 & & 0.127 \\
\hline & $(0.297)$ & & $(0.309)$ \\
\hline \multirow[t]{2}{*}{ bp_melaa } & $-0.389 * *$ & & -0.069 \\
\hline & $(0.174)$ & & $(0.185)$ \\
\hline \multirow[t]{2}{*}{ bp_asia } & -0.238 & & \\
\hline & $(0.151)$ & & \\
\hline \multirow[t]{2}{*}{ mig_ysm0_4 } & $-0.602 * * *$ & & $-1.017 * * *$ \\
\hline & $(0.180)$ & & $(0.205)$ \\
\hline \multirow[t]{2}{*}{ mig_ysm5_9 } & -0.157 & & $-0.469 * * *$ \\
\hline & $(0.152)$ & & $(0.172)$ \\
\hline \multirow[t]{2}{*}{ mig_ysm10_14 } & 0.114 & & -0.167 \\
\hline & $(0.166)$ & & $(0.180)$ \\
\hline \multirow[t]{2}{*}{ mig_ysm15_19 } & $0.445^{* *}$ & & 0.239 \\
\hline & $(0.177)$ & & $(0.185)$ \\
\hline \multicolumn{4}{|c|}{ Geographical variables } \\
\hline \multirow[t]{2}{*}{ geo_akl } & -0.051 & 0.007 & $-0.232 * * *$ \\
\hline & $(0.065)$ & $(0.076)$ & $(0.131)$ \\
\hline \multirow[t]{2}{*}{ geo_wel } & -0.104 & -0.074 & -0.228 \\
\hline & $(0.071)$ & (0.081) & (0.152) \\
\hline \multirow[t]{2}{*}{ geo_cant } & -0.101 & -0.081 & -0.239 \\
\hline & $(0.068)$ & $(0.074)$ & (0.169) \\
\hline \multirow[t]{2}{*}{ geo_mainurb } & -0.003 & 0.005 & -0.023 \\
\hline & $(0.066)$ & $(0.072)$ & $(0.172)$ \\
\hline \multirow[t]{2}{*}{ geo_rural } & $1.093 * * *$ & $1.124^{* * *}$ & $0.981 * * *$ \\
\hline & $(0.083)$ & $(0.089)$ & $(0.224)$ \\
\hline \multicolumn{4}{|l|}{ Year of survey } \\
\hline \multirow[t]{2}{*}{ gss10 } & $-0.108 * *$ & $-0.123 * *$ & -0.034 \\
\hline & $(0.055)$ & $(0.062)$ & $(0.122)$ \\
\hline \multirow[t]{2}{*}{ gss12 } & $-0.150 * * *$ & $-0.156 * * *$ & -0.118 \\
\hline & $(0.056)$ & $(0.063)$ & $(0.125)$ \\
\hline \multirow[t]{2}{*}{ Constant } & $-5.903 * * *$ & $-6.312 * * *$ & $-4.448 * * *$ \\
\hline & $(0.350)$ & $(0.404)$ & $(0.750)$ \\
\hline Observations & 15,541 & 11,993 & 3,548 \\
\hline Adjusted R-squared & 0.213 & 0.212 & 0.227 \\
\hline
\end{tabular}


Table 2: Ordered logit regression models of economic living standards of entrepreneurs

\begin{tabular}{|c|c|c|c|}
\hline \multirow[t]{2}{*}{ VARIABLES } & $\begin{array}{c}\text { (1) } \\
\text { hk_elsi_cat }\end{array}$ & $\begin{array}{c}\text { (2) } \\
\text { hk_elsi_cat }\end{array}$ & $\begin{array}{c}\text { (3) } \\
\text { hk_elsi_cat }\end{array}$ \\
\hline & Pooled & Native & Migrant \\
\hline \multicolumn{4}{|c|}{ Social capital variables } \\
\hline \multirow[t]{2}{*}{ geo_facilities } & $0.534 * * *$ & $0.539 * * *$ & $0.502^{*}$ \\
\hline & (0.135) & $(0.157)$ & $(0.266)$ \\
\hline \multirow[t]{2}{*}{ ks_safe } & $0.344 * * *$ & $0.358 * * *$ & $0.288^{*}$ \\
\hline & $(0.077)$ & $(0.087)$ & (0.171) \\
\hline \multirow[t]{2}{*}{ ks_help } & $0.662 * * *$ & $0.741 * * *$ & $0.503^{*}$ \\
\hline & $(0.160)$ & $(0.200)$ & $(0.274)$ \\
\hline \multirow[t]{2}{*}{ ks_included } & $0.872 * * *$ & $0.847^{* * *}$ & $0.972 * * *$ \\
\hline & $(0.075)$ & $(0.086)$ & $(0.157)$ \\
\hline \multirow[t]{2}{*}{ ks_vol } & 0.032 & 0.079 & -0.208 \\
\hline & (0.072) & (0.081) & (0.168) \\
\hline \multirow[t]{2}{*}{ ks_part } & -0.034 & -0.040 & 0.052 \\
\hline & $(0.072)$ & $(0.081)$ & (0.163) \\
\hline \multicolumn{4}{|c|}{ Human capital variables } \\
\hline \multirow[t]{2}{*}{ emp_part } & $-0.299 * * *$ & $-0.221 * *$ & $-0.606 * * *$ \\
\hline & $(0.084)$ & $(0.096)$ & $(0.182)$ \\
\hline \multirow[t]{2}{*}{ edu_yos } & $0.103^{* * *}$ & $0.098 * * *$ & $0.132 * * *$ \\
\hline & $(0.017)$ & (0.019) & $(0.038)$ \\
\hline \multirow[t]{2}{*}{ manager } & $0.425^{* * *}$ & $0.388 * * *$ & $0.533^{* *}$ \\
\hline & $(0.115)$ & $(0.130)$ & $(0.255)$ \\
\hline \multirow[t]{2}{*}{ professional } & $0.444 * * *$ & $0.414^{* * *}$ & $0.472^{*}$ \\
\hline & $(0.129)$ & (0.149) & $(0.270)$ \\
\hline \multirow[t]{2}{*}{ retail_admin } & 0.188 & 0.162 & 0.312 \\
\hline & (0.129) & $(0.146)$ & $(0.288)$ \\
\hline \multirow[t]{2}{*}{ trade_technical } & 0.018 & -0.042 & 0.217 \\
\hline & $(0.130)$ & $(0.146)$ & $(0.287)$ \\
\hline \multicolumn{4}{|c|}{ Demographic variables } \\
\hline \multirow[t]{2}{*}{ demo_partner } & $0.569 * * *$ & $0.610 * * *$ & 0.295 \\
\hline & $(0.082)$ & $(0.091)$ & $(0.201)$ \\
\hline \multirow[t]{2}{*}{ demo_age } & $0.035^{*}$ & 0.033 & 0.053 \\
\hline & $(0.018)$ & $(0.021)$ & (0.039) \\
\hline \multirow[t]{2}{*}{ demo_age2/100 } & -0.000 & -0.000 & -0.000 \\
\hline & $(0.000)$ & $(0.000)$ & $(0.000)$ \\
\hline \multirow[t]{2}{*}{ demo_child } & $-0.517^{* * *}$ & $-0.509 * * *$ & $-0.569 * * *$ \\
\hline & $(0.081)$ & $(0.092)$ & $(0.177)$ \\
\hline \multirow[t]{2}{*}{ demo_male } & -0.051 & -0.004 & -0.246 \\
\hline & $(0.079)$ & $(0.091)$ & $(0.170)$ \\
\hline \multicolumn{4}{|c|}{ Migrant and ethnicity variables } \\
\hline \multirow[t]{2}{*}{ eth_maori } & 0.012 & -0.001 & 1.448 \\
\hline & $(0.208)$ & $(0.210)$ & (1.683) \\
\hline \multirow[t]{2}{*}{ bp_nz_pacifica } & 0.335 & 0.322 & \\
\hline & $(0.564)$ & $(0.566)$ & \\
\hline bp_western & 0.384 & & \\
\hline & $(0.804)$ & & \\
\hline
\end{tabular}


Table 2 continued

\begin{tabular}{|c|c|c|c|}
\hline VARIABLES & (1) hk_elsi_cat & (2) hk_elsi_cat & (3)hk_elsi_cat \\
\hline & Pooled & Native & Migrant \\
\hline bp_pacifica & $\begin{array}{l}-1.017 \\
(0.961)\end{array}$ & & $\begin{array}{l}-1.435^{* * *} \\
(0.545)\end{array}$ \\
\hline \multirow[t]{2}{*}{ bp_apac } & -0.582 & & $-0.936 * *$ \\
\hline & $(0.910)$ & & $(0.453)$ \\
\hline \multirow[t]{2}{*}{ bp_melaa } & -0.117 & & $-0.461 *$ \\
\hline & $(0.831)$ & & $(0.244)$ \\
\hline \multirow[t]{2}{*}{ bp_asia } & -0.388 & & $-0.821 * * *$ \\
\hline & $(0.805)$ & & $(0.215)$ \\
\hline \multirow[t]{2}{*}{ mig_ysm0_4 } & -0.212 & & -0.101 \\
\hline & $(0.840)$ & & $(0.295)$ \\
\hline \multirow[t]{2}{*}{ mig_ysm5_9 } & -0.385 & & -0.198 \\
\hline & $(0.816)$ & & $(0.221)$ \\
\hline \multirow[t]{2}{*}{ mig_ysm10_14 } & -0.027 & & 0.128 \\
\hline & $(0.822)$ & & $(0.247)$ \\
\hline \multirow[t]{2}{*}{ mig_ysm15_19 } & -0.164 & & 0.057 \\
\hline & $(0.823)$ & & $(0.244)$ \\
\hline \multicolumn{4}{|c|}{ Geographical variables } \\
\hline \multirow[t]{2}{*}{ geo_akl } & 0.063 & 0.054 & 0.123 \\
\hline & (0.095) & $(0.111)$ & $(0.196)$ \\
\hline \multirow[t]{2}{*}{ geo_wel } & 0.006 & -0.044 & 0.187 \\
\hline & $(0.105)$ & $(0.120)$ & $(0.227)$ \\
\hline \multirow[t]{2}{*}{ geo_cant } & 0.002 & 0.041 & -0.160 \\
\hline & $(0.099)$ & $(0.108)$ & $(0.255)$ \\
\hline \multirow[t]{2}{*}{ geo_mainurb } & 0.077 & 0.151 & -0.377 \\
\hline & (0.098) & $(0.106)$ & $(0.263)$ \\
\hline \multirow[t]{2}{*}{ geo_rural } & 0.146 & $0.205^{*}$ & -0.351 \\
\hline & (0.114) & $(0.123)$ & $(0.315)$ \\
\hline \multicolumn{4}{|c|}{ Year of survey } \\
\hline \multirow[t]{2}{*}{ gss10 } & $-0.177^{* *}$ & $-0.183^{* *}$ & -0.137 \\
\hline & $(0.079)$ & $(0.089)$ & (0.179) \\
\hline \multirow[t]{2}{*}{ gss12 } & $-0.180 * *$ & $-0.201 * *$ & -0.085 \\
\hline & $(0.082)$ & $(0.092)$ & $(0.187)$ \\
\hline \multirow[t]{2}{*}{ Cut 1 constant } & -0.007 & -0.115 & 0.100 \\
\hline & $(0.574)$ & $(0.666)$ & (1.197) \\
\hline \multirow[t]{2}{*}{ Cut 2 constant } & $1.362 * *$ & $1.440 * *$ & 1.052 \\
\hline & $(0.548)$ & $(0.629)$ & (1.171) \\
\hline \multirow[t]{2}{*}{ Cut 3 constant } & $2.454 * * *$ & $2.560 * * *$ & $2.066^{*}$ \\
\hline & $(0.544)$ & $(0.624)$ & $(1.165)$ \\
\hline \multirow[t]{2}{*}{ Cut 4 constant } & $3.478 * * *$ & $3.548 * * *$ & $3.240 * * *$ \\
\hline & (0.545) & $(0.624)$ & $(1.168)$ \\
\hline \multirow[t]{2}{*}{ Cut 5 constant } & $4.750 * * *$ & $4.825^{* * *}$ & $4.513^{* * *}$ \\
\hline & $(0.548)$ & $(0.628)$ & $(1.174)$ \\
\hline \multirow[t]{2}{*}{ Cut 6 constant } & $6.800 * * *$ & $6.849 * * *$ & $6.709 * * *$ \\
\hline & $(0.554)$ & $(0.634)$ & $(1.186)$ \\
\hline Observations & 3,180 & 2,516 & 664 \\
\hline r2_p & 0.069 & 0.064 & 0.093 \\
\hline
\end{tabular}


Table 3: OLS regression models of the natural logarithm of personal income of entrepreneurs

\begin{tabular}{|c|c|c|c|}
\hline \multirow[t]{2}{*}{ VARIABLES } & $\begin{array}{c}(1) \\
\text { Inpinc }\end{array}$ & $\begin{array}{c}(2) \\
\text { Inpinc }\end{array}$ & $\begin{array}{c}(3) \\
\text { Inpinc }\end{array}$ \\
\hline & Pooled & Native & Migrant \\
\hline \multicolumn{4}{|c|}{ Social capital variables } \\
\hline \multirow{2}{*}{ geo_facilities } & 0.068 & 0.085 & 0.007 \\
\hline & $(0.052)$ & $(0.060)$ & $(0.111)$ \\
\hline \multirow[t]{2}{*}{ ks_safe } & $0.067^{* *}$ & $0.058 *$ & 0.094 \\
\hline & $(0.030)$ & $(0.033)$ & $(0.070)$ \\
\hline \multirow[t]{2}{*}{ ks_help } & 0.065 & 0.093 & 0.019 \\
\hline & $(0.064)$ & $(0.077)$ & $(0.116)$ \\
\hline \multirow[t]{2}{*}{ ks_included } & $0.050^{*}$ & $0.061^{*}$ & 0.005 \\
\hline & $(0.029)$ & $(0.033)$ & $(0.065)$ \\
\hline \multirow[t]{2}{*}{ ks_vol } & -0.034 & -0.031 & -0.048 \\
\hline & $(0.028)$ & $(0.031)$ & (0.069) \\
\hline \multirow[t]{2}{*}{ ks_part } & $0.052^{*}$ & 0.033 & $0.136^{* *}$ \\
\hline & $(0.028)$ & (0.031) & $(0.067)$ \\
\hline \multicolumn{4}{|c|}{ Human capital variables } \\
\hline \multirow[t]{2}{*}{ edu_negatt } & -0.014 & -0.008 & 0.053 \\
\hline & $(0.078)$ & $(0.082)$ & $(0.242)$ \\
\hline \multirow[t]{2}{*}{ emp_part } & $-0.550 * * *$ & $-0.529 * * *$ & $-0.614 * * *$ \\
\hline & $(0.033)$ & $(0.036)$ & $(0.076)$ \\
\hline \multirow[t]{2}{*}{ edu_yos } & $0.040 * * *$ & $0.044 * * *$ & $0.030 *$ \\
\hline & $(0.006)$ & $(0.007)$ & $(0.015)$ \\
\hline \multirow[t]{2}{*}{ manager } & $0.209 * * *$ & $0.150 * * *$ & $0.391^{* * *}$ \\
\hline & $(0.045)$ & $(0.050)$ & $(0.106)$ \\
\hline \multirow[t]{2}{*}{ professional } & $0.309 * * *$ & $0.256 * * *$ & $0.463^{* * *}$ \\
\hline & $(0.050)$ & $(0.057)$ & $(0.110)$ \\
\hline \multirow[t]{2}{*}{ retail_admin } & $0.141^{* * *}$ & 0.080 & $0.332 * * *$ \\
\hline & $(0.051)$ & $(0.056)$ & $(0.119)$ \\
\hline \multirow[t]{2}{*}{ trade_technical } & 0.076 & 0.024 & $0.224^{*}$ \\
\hline & $(0.051)$ & $(0.057)$ & $(0.121)$ \\
\hline \multicolumn{4}{|c|}{ Demographic variables } \\
\hline \multirow[t]{2}{*}{ demo_partner } & -0.018 & -0.000 & -0.094 \\
\hline & $(0.032)$ & $(0.035)$ & $(0.083)$ \\
\hline \multirow[t]{2}{*}{ demo_age } & $0.042 * * *$ & $0.043 * * *$ & $0.035^{* *}$ \\
\hline & $(0.007)$ & $(0.008)$ & $(0.017)$ \\
\hline \multirow[t]{2}{*}{ demo_age2/100 } & $-0.000 * * *$ & $-0.000 * * *$ & $-0.000 *$ \\
\hline & $(0.000)$ & $(0.000)$ & $(0.000)$ \\
\hline \multirow[t]{2}{*}{ demo_child } & 0.030 & 0.017 & 0.083 \\
\hline & $(0.032)$ & $(0.035)$ & $(0.073)$ \\
\hline \multirow[t]{2}{*}{ demo_male } & $0.324^{* * *}$ & $0.307 * * *$ & $0.392 * * *$ \\
\hline & $(0.031)$ & $(0.035)$ & $(0.071)$ \\
\hline \multicolumn{4}{|c|}{ Migrant and ethnicity variables } \\
\hline \multirow[t]{2}{*}{ eth_maori } & -0.075 & -0.059 & -0.866 \\
\hline & $(0.082)$ & $(0.081)$ & $(0.780)$ \\
\hline bp_western & -0.341 & & \\
\hline & $(0.361)$ & & \\
\hline
\end{tabular}




\begin{tabular}{|c|c|c|c|}
\hline \multirow[t]{2}{*}{ VARIABLES } & $\begin{array}{c}\text { (1) } \\
\text { Inpinc }\end{array}$ & $\begin{array}{c}(2) \\
\text { Inpinc }\end{array}$ & $\begin{array}{c}(3) \\
\text { Inpinc }\end{array}$ \\
\hline & Pooled & Native & Migrant \\
\hline bp_nz_pacifica & $\begin{array}{c}0.338 \\
(0.208)\end{array}$ & $\begin{array}{c}0.339 * \\
(0.205)\end{array}$ & \\
\hline bp_pacifica & $\begin{array}{l}-0.468 \\
(0.421)\end{array}$ & & $\begin{array}{l}-0.158 \\
(0.238)\end{array}$ \\
\hline bp_apac & $\begin{array}{l}-0.752^{*} \\
(0.401)\end{array}$ & & $\begin{array}{l}-0.414^{* *} \\
(0.198)\end{array}$ \\
\hline bp_melaa & $\begin{array}{l}-0.308 \\
(0.370)\end{array}$ & & $\begin{array}{c}0.047 \\
(0.100)\end{array}$ \\
\hline bp_asia & $\begin{array}{l}-0.602^{*} \\
(0.361)\end{array}$ & & $\begin{array}{l}-0.262^{* * *} \\
(0.091)\end{array}$ \\
\hline mig_ysm0_4 & $\begin{array}{c}0.069 \\
(0.372)\end{array}$ & & $\begin{array}{l}-0.254^{* *} \\
(0.119)\end{array}$ \\
\hline mig_ysm5_9 & $\begin{array}{c}0.167 \\
(0.365)\end{array}$ & & $\begin{array}{l}-0.128 \\
(0.094)\end{array}$ \\
\hline mig_ysm10_14 & $\begin{array}{c}0.171 \\
(0.367)\end{array}$ & & $\begin{array}{l}-0.127 \\
(0.103)\end{array}$ \\
\hline mig_ysm15_19 & $\begin{array}{c}0.222 \\
(0.368)\end{array}$ & & $\begin{array}{l}-0.096 \\
(0.103)\end{array}$ \\
\hline \multicolumn{4}{|c|}{ Geographical variables } \\
\hline geo_akl & $\begin{array}{l}0.145^{* * *} \\
(0.038)\end{array}$ & $\begin{array}{l}0.129 * * * \\
(0.043)\end{array}$ & $\begin{array}{c}0.149 * \\
(0.082)\end{array}$ \\
\hline geo_wel & $\begin{array}{l}0.097^{* *} \\
(0.041)\end{array}$ & $\begin{array}{c}0.073 \\
(0.046)\end{array}$ & $\begin{array}{c}0.139 \\
(0.094)\end{array}$ \\
\hline geo_cant & $\begin{array}{l}-0.047 \\
(0.039)\end{array}$ & $\begin{array}{c}0.021 \\
(0.042)\end{array}$ & $\begin{array}{l}-0.394^{* * *} \\
(0.105)\end{array}$ \\
\hline geo_mainurb & $\begin{array}{c}0.033 \\
(0.039)\end{array}$ & $\begin{array}{c}0.029 \\
(0.041)\end{array}$ & $\begin{array}{c}0.069 \\
(0.108)\end{array}$ \\
\hline geo_rural & $\begin{array}{c}0.053 \\
(0.045)\end{array}$ & $\begin{array}{c}0.043 \\
(0.048)\end{array}$ & $\begin{array}{c}0.120 \\
(0.131)\end{array}$ \\
\hline \multicolumn{4}{|l|}{ Year of survey } \\
\hline gss10 & $\begin{array}{l}-0.043 \\
(0.031)\end{array}$ & $\begin{array}{l}-0.039 \\
(0.034)\end{array}$ & $\begin{array}{l}-0.079 \\
(0.074)\end{array}$ \\
\hline gss12 & $\begin{array}{c}0.019 \\
(0.032)\end{array}$ & $\begin{array}{c}0.011 \\
(0.035)\end{array}$ & $\begin{array}{c}0.028 \\
(0.077)\end{array}$ \\
\hline Constant & $\begin{array}{l}8.525^{* * *} \\
(0.210)\end{array}$ & $\begin{array}{l}8.464 * * * \\
(0.235)\end{array}$ & $\begin{array}{l}8.701^{* * *} \\
(0.490)\end{array}$ \\
\hline Observations & 3,116 & 2,465 & 651 \\
\hline Adjusted R-squared & 0.223 & 0.208 & 0.265 \\
\hline
\end{tabular}




\section{Appendix}

Table A1: ELSI Short Form Score Range

\begin{tabular}{|l|c|l|}
\hline \multicolumn{3}{|l|}{ Score ranges for the ELSI Short Form } \\
\hline ELSI Short From score & Living standard level & Label \\
\hline $0-8$ & 1 & Severe hardship \\
\hline $9-12$ & 2 & Significant hardship \\
\hline $13-16$ & 3 & Some hardship \\
\hline $17-20$ & 4 & Fairly comfortable \\
\hline $21-24$ & 5 & Comfortable \\
\hline $25-28$ & 6 & Good \\
\hline $29-31$ & 7 & Very good \\
\hline
\end{tabular}

Source: Jensen et al. (2005)

Table A2: Data Dictionary

\section{Dependent (Left-hand side) Variables}

\begin{tabular}{|l|l|l|}
\hline Name & Description & Relevance to Research \\
\hline ent_slfemp & $\begin{array}{l}\text { Sources of personal income } \\
\text { include self-employment or } \\
\text { owning a business }\end{array}$ & $\begin{array}{l}\text { This binary variable (yes=1, } \\
\text { no=0) identifies whether the } \\
\text { respondent is considered an } \\
\text { entrepreneur. }\end{array}$ \\
\hline hk_elsi_cat & $\begin{array}{l}\text { Economic Living Standard Index } \\
\text { (Short Form) }\end{array}$ & $\begin{array}{l}\text { This is the selected measure } \\
\text { of economic standard of } \\
\text { living. See Table A1. }\end{array}$ \\
\hline Inpinc & The natural logarithm of & $\begin{array}{l}\text { This measure of income is } \\
\text { that of the person identified } \\
\text { as the entrepreneur (and } \\
\text { may be less than household } \\
\text { income). }\end{array}$ \\
\hline
\end{tabular}




\begin{tabular}{|c|c|c|}
\hline \multicolumn{3}{|c|}{ Independent (Right-hand side) Variables } \\
\hline Name & Description & Relevance to Research \\
\hline \multicolumn{3}{|c|}{ Social capital variables - All binary (yes $=1, \mathrm{no}=0$ ) } \\
\hline geo_facilities & $\begin{array}{l}\text { Access to sufficient facilities, } \\
\text { e.g., shops and schools in the } \\
\text { local area }\end{array}$ & $\begin{array}{l}\text { Access to adequate facilities } \\
\text { is used as a proxy for social } \\
\text { capital }\end{array}$ \\
\hline ks_safe & $\begin{array}{l}\text { The respondent felt safe walking } \\
\text { alone at night in their } \\
\text { neighborhood }\end{array}$ & $\begin{array}{l}\text { Feelings of safety are } \\
\text { related to trust, which is } \\
\text { crucial for social capital } \\
\text { development. }\end{array}$ \\
\hline ks_help & $\begin{array}{l}\text { Availability of help in time of } \\
\text { need }\end{array}$ & $\begin{array}{l}\text { Reciprocity and ability to } \\
\text { ask for help from informal } \\
\text { networks is a measure of } \\
\text { social capital. }\end{array}$ \\
\hline ks_included & $\begin{array}{l}\text { The respondent did not feel } \\
\text { isolated from others in the last } \\
\text { four weeks }\end{array}$ & $\begin{array}{l}\text { Active participation in } \\
\text { informal networks is used as } \\
\text { a proxy for social capital. }\end{array}$ \\
\hline ks_vol & $\begin{array}{l}\text { The respondent has done } \\
\text { volunteer work in the last four } \\
\text { weeks }\end{array}$ & $\begin{array}{l}\text { Volunteering is used as a } \\
\text { proxy for social capital. }\end{array}$ \\
\hline ks_part & $\begin{array}{l}\text { The respondent has taken part in } \\
\text { an activity (not as a volunteer) } \\
\text { organized by a group or } \\
\text { organization in the last four } \\
\text { weeks }\end{array}$ & $\begin{array}{l}\text { This is evidence of social } \\
\text { networking that is used as a } \\
\text { proxy for social capital. }\end{array}$ \\
\hline \multicolumn{3}{|c|}{ Demographic variables } \\
\hline demo_partner & Marital status & $\begin{array}{l}\text { Having a partner (yes=1, } \\
\text { no=0) will influence the } \\
\text { decision to start a business. }\end{array}$ \\
\hline demo_age & Age & $\begin{array}{l}\text { Age may affect attitude to } \\
\text { risk, but also access to } \\
\text { capital and business } \\
\text { experience. }\end{array}$ \\
\hline demo_child & $\begin{array}{l}\text { Number of dependent children } \\
\text { in family }\end{array}$ & $\begin{array}{l}\text { The respondent's willingness } \\
\text { to take on risk may be affected } \\
\text { by having dependants to care } \\
\text { for. }\end{array}$ \\
\hline demo_male & Sex & $\begin{array}{l}\text { Most studies suggest that the } \\
\text { majority of entrepreneurs are } \\
\text { men (yes }=1, \text { no=0). }\end{array}$ \\
\hline
\end{tabular}




\begin{tabular}{|c|c|c|}
\hline \multicolumn{3}{|c|}{ Human capital variables } \\
\hline edu_negatt & Attitude to education & $\begin{array}{l}\text { Being a high school dropout } \\
\text { (yes }=1, \text { no=0) can lead to } \\
\text { necessity entrepreneurship. }\end{array}$ \\
\hline emp_part & Part-time employment & $\begin{array}{l}\text { Those in part time } \\
\text { employment (yes=1, no=0) } \\
\text { are less likely to have } \\
\text { income from self- } \\
\text { employment or from } \\
\text { owning a business. }\end{array}$ \\
\hline emp_fixt & Fixed-term employment & $\begin{array}{l}\text { Those in fixed-term } \\
\text { employment (yes }=1, \text { no=0) are } \\
\text { less likely to have income from } \\
\text { self-employment or from } \\
\text { owning a business. }\end{array}$ \\
\hline emp_perm & Permanent employment & $\begin{array}{l}\text { Those in permanent } \\
\text { employment (yes }=1, \text { no= } 0 \text { ) are } \\
\text { less likely to have income from } \\
\text { self-employment or from } \\
\text { owning a business. }\end{array}$ \\
\hline edu_yos & Years of schooling & $\begin{array}{l}\text { A higher level of education is } \\
\text { likely to be very important for } \\
\text { the success of a business or } \\
\text { self-employment and leads to } \\
\text { opportunity entrepreneurship. }\end{array}$ \\
\hline edu_os & Overseas education & $\begin{array}{l}\text { The effect of overseas } \\
\text { education (yes=1, no=0) on } \\
\text { self-employment or business } \\
\text { income may differ between } \\
\text { the New Zealand born and } \\
\text { immigrants. }\end{array}$ \\
\hline postgrad & Post-graduate qualification & $\begin{array}{l}\text { A qualification in conducting } \\
\text { research (yes }=1, \text { no }=0 \text { ) is less } \\
\text { likely to lead to self- } \\
\text { employment. }\end{array}$ \\
\hline trade & Trade qualification & $\begin{array}{l}\text { A trade qualification (yes }=1 \text {, } \\
\text { no }=0 \text { ) is more likely to lead to } \\
\text { self-employment. }\end{array}$ \\
\hline
\end{tabular}




\begin{tabular}{|c|c|c|}
\hline manager & $\begin{array}{l}\text { Self-employed and business } \\
\text { owners in management }\end{array}$ & $\begin{array}{l}\text { Those in management } \\
\text { (yes }=1, \text { no }=0 \text { ) are likely to } \\
\text { have higher living standards } \\
\text { and income. }\end{array}$ \\
\hline professional & $\begin{array}{l}\text { Professional self-employed and } \\
\text { business owners }\end{array}$ & $\begin{array}{l}\text { Professionals (yes }=1, \mathrm{no}=0 \text { ) } \\
\text { are likely to have higher } \\
\text { living standards and } \\
\text { income. }\end{array}$ \\
\hline retail_admin & $\begin{array}{l}\text { Self-employed and business } \\
\text { owners in retail or } \\
\text { administration }\end{array}$ & $\begin{array}{l}\text { These types of entrepreneurs } \\
\text { (yes }=1, \text { no }=0 \text { ) are likely to } \\
\text { have higher living standards } \\
\text { and income. }\end{array}$ \\
\hline trade_technical & $\begin{array}{l}\text { Self-employed and business } \\
\text { owners in trade or technical } \\
\text { occupations }\end{array}$ & $\begin{array}{l}\text { These types of entrepreneurs } \\
\text { (yes }=1, \text { no }=0 \text { ) are likely to } \\
\text { have higher living standards } \\
\text { and income. }\end{array}$ \\
\hline \multicolumn{3}{|c|}{ Migrant and ethnicity variables } \\
\hline eth_maori & $\begin{array}{l}\text { Identifies as having the } \\
\text { Māori ethnicity }\end{array}$ & $\begin{array}{l}\text { The cultural characteristics of } \\
\text { this ethnic group (yes }=1, \text { no= } 0 \text { ) } \\
\text { may influence the decision for } \\
\text { the respondent to become an } \\
\text { entrepreneur. }\end{array}$ \\
\hline bp_nz_pacifica & $\begin{array}{l}\text { Born in New Zealand but } \\
\text { identifies as Pacifica }\end{array}$ & $\begin{array}{l}\text { The cultural characteristics of } \\
\text { this ethnic group (yes }=1, \text { no }=0 \text { ) } \\
\text { may influence the decision for } \\
\text { the respondent to become an } \\
\text { entrepreneur. }\end{array}$ \\
\hline bp_western & $\begin{array}{l}\text { Born in Europe, Americas or } \\
\text { Australia }\end{array}$ & $\begin{array}{l}\text { The cultural characteristics of } \\
\text { this ethnic group (yes }=1, \text { no }=0 \text { ) } \\
\text { may influence the decision for } \\
\text { the respondent to become an } \\
\text { entrepreneur. }\end{array}$ \\
\hline bp_pacifica & Born in the Pacific Region & $\begin{array}{l}\text { The cultural characteristics of } \\
\text { this ethnic group (yes }=1, \text { no= } 0 \text { ) } \\
\text { may influence the decision for } \\
\text { the respondent to become an } \\
\text { entrepreneur. }\end{array}$ \\
\hline bp_apac & $\begin{array}{l}\text { Pacific Born who identify as } \\
\text { Asian }\end{array}$ & $\begin{array}{l}\text { The cultural characteristics of } \\
\text { this ethnic group (yes }=1, \text { no }=0 \text { ) } \\
\text { may influence the decision for } \\
\text { the respondent to become an } \\
\text { entrepreneur. }\end{array}$ \\
\hline
\end{tabular}




\begin{tabular}{|c|c|c|}
\hline bp_melaa & $\begin{array}{l}\text { Born in the Middle East or } \\
\text { Africa Regions (this region } \\
\text { also included those who did } \\
\text { not answer the question). }\end{array}$ & $\begin{array}{l}\text { The cultural characteristics of } \\
\text { this ethnic group (yes }=1, \text { no }=0 \text { ) } \\
\text { may influence the decision for } \\
\text { the respondent to become an } \\
\text { entrepreneur. }\end{array}$ \\
\hline bp_asia & $\begin{array}{l}\text { Born in the Asian Region. } \\
\text { Made up of those born in } \\
\text { South-East Asia, North-East } \\
\text { Asia and Rest of Asia. }\end{array}$ & $\begin{array}{l}\text { The cultural characteristics of } \\
\text { this ethnic group (yes }=1, \text { no }=0 \text { ) } \\
\text { may influence the decision for } \\
\text { the respondent to become an } \\
\text { entrepreneur. }\end{array}$ \\
\hline mig_ysm0_4 & $0-4$ years since migration & $\begin{array}{l}\text { Yes }=1, \text { no }=0 . \text { The longer a } \\
\text { migrant has been in the host } \\
\text { country the greater their } \\
\text { human capital and networks } \\
\text { that benefit } \\
\text { entrepreneurship. }\end{array}$ \\
\hline mig_ysm5_9 & 5-9 years since migration & $\begin{array}{l}\text { Yes }=1, \text { no }=0 \text {. The longer a } \\
\text { migrant has been in the host } \\
\text { country the greater their } \\
\text { human capital and networks } \\
\text { that benefit } \\
\text { entrepreneurship. }\end{array}$ \\
\hline mig_ysm10_14 & $10-14$ years since migration & $\begin{array}{l}\text { Yes }=1, \text { no }=0 . \text { The longer a } \\
\text { migrant has been in the host } \\
\text { country the greater their } \\
\text { human capital and networks } \\
\text { that benefit } \\
\text { entrepreneurship. }\end{array}$ \\
\hline mig_ysm15_19 & $15-19$ years since migration & $\begin{array}{l}\text { Yes }=1, \text { no }=0 \text {. The longer a } \\
\text { migrant has been in the host } \\
\text { country the greater their } \\
\text { human capital and networks } \\
\text { that benefit } \\
\text { entrepreneurship. }\end{array}$ \\
\hline \multicolumn{3}{|c|}{ Geographical variables } \\
\hline geo_akl & Auckland Region & $\begin{array}{l}\text { Yes }=1, \text { no }=0 . \\
\text { Locational dummy variables } \\
\text { account for spatial variation in } \\
\text { necessity and opportunity } \\
\text { entrepreneurship. Auckland is } \\
\text { the largest city of New } \\
\text { Zealand. }\end{array}$ \\
\hline
\end{tabular}




\begin{tabular}{|c|c|c|}
\hline geo_wel & Wellington Region & $\begin{array}{l}\text { Yes }=1, \text { no= } 0 \text {. Locational } \\
\text { dummy variables account } \\
\text { for spatial variation in } \\
\text { necessity and opportunity } \\
\text { entrepreneurship. } \\
\text { Wellington is the capital } \\
\text { city of New Zealand. }\end{array}$ \\
\hline geo_cant & Canterbury Region & $\begin{array}{l}\text { Yes }=1, \text { no=0. Locational } \\
\text { dummy variables account } \\
\text { for spatial variation in } \\
\text { necessity and opportunity } \\
\text { entrepreneurship. } \\
\text { Canterbury is the largest } \\
\text { region in the South Island. }\end{array}$ \\
\hline geo_mainurb & Main Urban Area & $\begin{array}{l}\text { Yes }=1, \text { no=0. Locational } \\
\text { dummy variables account for } \\
\text { spatial variation in necessity } \\
\text { and opportunity } \\
\text { entrepreneurship. }\end{array}$ \\
\hline geo_rural & Rural Area & $\begin{array}{l}\text { Yes }=1, \text { no }=0 \text {. This variable } \\
\text { reflects self-employment and } \\
\text { business ownership in farming. }\end{array}$ \\
\hline \multicolumn{3}{|c|}{ Year of the survey } \\
\hline gss10 & Year dummy & $\begin{array}{l}\text { The observation was obtained } \\
\text { from the } 2010 \text { New Zealand } \\
\text { General Social Survey (yes=1, } \\
\text { no=0). }\end{array}$ \\
\hline gss12 & Year dummy & $\begin{array}{l}\text { The observation was obtained } \\
\text { from the } 2012 \text { New Zealand } \\
\text { General Social Survey (yes }=1 \text {, } \\
\text { no=0). }\end{array}$ \\
\hline
\end{tabular}

